\title{
Hit and Miss: Leverage, Sacrifice, and Refusal to Deal in the Supreme Court Decision in Trinko
}

\author{
By Nicholas Economides*
}

October 2006

\begin{abstract}
$\underline{\text { Abstract }}$
Under the rules of the Telecommunications Act of 1996, incumbent local exchange carriers, including Verizon, were obligated to lease parts of their local telecommunications network to any firm at "cost plus a reasonable profit" prices which could combine them at will, add retailing services and sell local telecommunication service as a rival to the incumbent. AT\&T, an entrant in local telecommunications, leased parts of Verizon's network. Trinko, a local telecommunications services customer of AT\&T, sued Verizon alleging various anti-competitive actions of Verizon against AT\&T, including that Verizon raised the costs of AT\&T, its downstream retail rival. The Supreme Court held that Trinko's complaint failed to state a claim under $\S 2$ of the Sherman Act, and dismissed the complaint. I argue that Verizon had two monopolies in local telecommunications: a monopoly of the local telecommunications network, as well as a monopoly in retail local telecommunications services. The 1996 Act allowed for competition in retail services and also imposed cost-based pricing on leases of Verizon's network. Verizon, unable to increase the lease price on its network, reverted to raisingrivals-costs strategies against its retail competitors. Thus, Verizon used its monopoly of the network infrastructure to disadvantage entrants in retail. In doing so, Verizon lost short term profits that it would have earned from leasing its network to entrants, since the 1996 Act had set the lease price at cost plus "reasonable profit." Thus, Verizon is liable if the "sacrifice principle" is applied. According to the sacrifice principle, a defendant is liable if its conduct "involves a sacrifice of short-term profits or goodwill that makes sense only insofar as it helps the defendant maintain or obtain monopoly power."

Key words: Vertical Leverage, Refusal to Deal, Monopoly, Sacrifice Principle, Trinko
\end{abstract}

* Stern School of Business, NYU, 44 West $4^{\text {th }}$ Street, New York, NY 10012, email: economides@stern.nyu.edu, www: http://www.stern.nyu.edu/networks/, Tel. (212) 9980864, FAX (212) 995-4218, and Executive Director, NET Institute, http://www.NETinst.org . 


\section{Introduction}

The Law Offices of Curtis V. Trinko, a law partnership in Brooklyn, New York, bought local telecommunications services from AT\&T. AT\&T was providing these services by combining leased parts of the Verizon local telecommunications network (unbundled network elements, or "UNEs") and adding retail services of its own, such as billing and marketing. In Verizon Communications Inc. v. Law Offices of Curtis V. Trinko, ${ }^{1}$ Trinko sued Verizon for raising the costs of its retail rival AT\&T (which had entered the market as a competitive local exchange carrier, or "CLEC") and otherwise disadvantaging AT\&T through anti-competitive conduct (including discrimination in fulfilling customer transfer orders to entrants) under Section 2 of the Sherman Act. ${ }^{2}$

The district court dismissed all the claims brought in Trinko and accepted the defendant's view that a breach of the interconnection agreement between Verizon and a CLEC should be remedied through an administrative process. The court also noted that antitrust litigation would disrupt the regulatory process of implementing the Telecommunications Act of 1996 ("1996 Act”). ${ }^{3}$ The Second Circuit Court of Appeals reversed, stating that it was "unlikely that allowing antitrust suits would substantially disrupt the regulatory proceedings mandated by the Telecommunications Act." ${ }^{4}$ The Second Circuit observed that

\footnotetext{
${ }^{1} 540$ U.S. 398 (2004).

${ }^{2} I d$. at 402-05. Trinko originally sued NYNEX, which was later bought by Bell Atlantic. Bell Atlantic merged with GTE to created Verizon.

${ }^{3}$ Law Offices of Curtis V. Trinko v. Bell Atlantic Corp., 123 F. Supp. 2d 738, 745 (S.D.N.Y. 2000).

${ }^{4}$ Law Offices of Curtis V. Trinko v. Bell Atlantic Corp., 305 F.3d 89, 113 (2d Cir. 2002).
} 
while ideally, the regulatory process alone would be enough to bring competition to the local phone service markets, it is possible that the antitrust laws will be needed to supplement the regulatory scheme, especially with respect to injury caused to consumers. ${ }^{5}$

The decision of the Second Circuit to allow the antitrust claim to continue to trial implies that Verizon's failure to lease parts of its local network to rivals according to the rules of the Telecommunications Act could result in monopolization once all the facts were proven at trial. ${ }^{6}$ The Supreme Court, however, decided that Trinko failed to state a claim under section 2 of the Sherman Act, and dismissed the complaint. ${ }^{7}$

The Supreme Court gave no weight to the key vertical issue in Trinko. Verizon had two monopolies in local telecommunications: a monopoly of the local telecommunications network infrastructure (NET), as well as a monopoly in retailing services (retail). These two monopolies were vertically related. That is, to provide local telecommunications services, a firm needed to combine the use of the local telecommunications network infrastructure with retail services. Moreover, retail services on their own had no value unless combined with the use of the local telecommunications network infrastructure.

The 1996 Act allowed entrants to lease any part of the incumbent's (Verizon's) local telecommunications network infrastructure at cost plus a reasonable profit. AT\&T and a number of other companies leased from Verizon parts of its local

\footnotetext{
${ }^{5} 305$ F. 3d at 112.

${ }^{6} 305$ F. 3d at 113.

${ }^{7}$ Trinko, 540 U.S. at 416.
} 
telecommunications network and became Verizon's competitors in providing retail services to customers like Trinko. Verizon leveraged its monopoly of local telecommunications network infrastructure by raising the costs or decreasing the quality of services of rival local telecommunications services providers so that such rivals were disadvantaged. Verizon's incentive to raise the costs of its retail rivals was to preserve its monopoly in the retail part of local telecommunications services.

By raising the costs of retail rivals, Verizon lowered the number of leases of unbundled network elements bought by retail rivals, and thus incurred a revenue sacrifice because Verizon's lease prices were guaranteed by regulation to be above cost. The fact that Verizon incurred a short-term revenue sacrifice as a direct effect of its actions (in raising the costs or decreasing the quality of services of rival local telecommunications retailers) is an indication that the actions must have benefited Verizon in the long run by foreclosing competition. Thus, it may be inferred that Verizon's actions (resulting in short term profits sacrifice) were anti-competitive.

The fundamental issue is when a multi-product monopolist has an obligation to sell to companies a product or service that they may combine with products of their own to sell as substitutes to other products that the monopolist sells. Thus, the crucial issue is about compelling a monopolist to sell outputs that are used as inputs by rivals of the monopolist in other markets.

A number of observations are in order. First, such a situation is not uncommon. Multi-product monopolists are very common in many industries. Buyers are often companies that combine the monopolist's outputs and sell related products. Second, in the absence of price discrimination or bundling considerations or competition with the 
monopolist in some other market, the monopolist would prefer to sell at a monopoly price than not sell at all. Third, under the same conditions, the monopolist prefers to sell at a price that exceeds unit cost rather than not sell at all. It follows that when a monopolist refuses to sell, and therefore sacrifices short term profits, it must be guided by a long run benefit that he would receive if through its actions competitors are foreclosed or otherwise disadvantaged. These actions would be anti-competitive. Additionally, strategies by the multi-product monopolist that raise rivals' costs can have the same effect on competition as a refusal to deal in the required input. A regulated multi-product monopolist may have a greater incentive to resort to raising rivals' costs strategies when regulation prevents it from setting monopoly prices.

The rest of the paper is organized as follows. Section II puts the Trinko case in the context of the continuing deregulation in the telecommunications sector. I discuss the breakup of AT\&T in 1981 and the wisdom of the imposition of line-of-business restrictions on the local monopolists coming out of the old AT\&T so that they would not foreclose long distance competitors. Additionally, I discuss the major provisions of the 1996 Act, and how they apply to Trinko. In section III, discusses the Supreme Court's decision in Trinko and various problems that arise after close examination of the decision. Section IV discusses the profit sacrifice principle and its application in Trinko. Section V has concluding remarks.

\section{The Trinko Case in the Context of Telecommunications Deregulation}

The Trinko case is better understood in the context of the evolution of telecommunications markets in the United States. After a multi-year suit by the 
Department of Justice, ${ }^{8}$ AT\&T agreed to be broken into eight pieces: AT\&T itself, which retained the long distance lines, the equipment division (Western Electric) and most of Bell Laboratories, and seven Regional Bell Operating Companies ("RBOCs") each of which retained a monopoly in its region for local telecommunications services. ${ }^{9}$ The logic of the 1981 AT\&T breakup was that, given the technology at that time, competition was economically feasible in long distance telecommunications services but uneconomic in local telecommunications service. The local telecommunications network was considered to have been too expensive to replicate compared to the revenues that it could create, especially from residential and small business customers. Thus, assuming that local telecommunications was a natural monopoly, the U.S. Department of Justice allowed each RBOC to remain a monopolist in local telecommunications in its geographic region. ${ }^{10}$

The Modification of Final Judgment ("MFJ") 11 that finalized the AT\&T breakup imposed line of business restrictions that prevented RBOCs from entering the long distance market. This was because of the key vertical concern that is also the crucial

\footnotetext{
${ }^{8}$ United States v. American Telephone and Telegraph Co. 642 F.2d 1285 (D.C. Cir. 1980).

${ }^{9}$ The RBOCs were Ameritech, Bell Atlantic, Bell South, NYNEX, Pacific Bell, U.S. West, and Southwestern Bell.

${ }^{10}$ The logic of the breakup and the belief that local telecommunications was a natural monopoly at the time companies are based on private communication of the author with William Baxter, Assistant Attorney General for Antitrust and chief architect of the settlement that resulted in the 1982 breakup of AT\&T. See also Roger G. Noll \& Bruce M. Owen, The Anticompetitive Uses of Regulation: United States v. AT\&T, in J. KwoKa \& L. White, The ANTitrust ReVolution (1999).

${ }^{11}$ Modification of Final Judgment or MFJ, formally United States v. American Tel. and Tel. Co., 552 F. Supp. 131 (D.C. Cir. 1982) (finalizing the antitrust suit of the United States against AT\&T).
} 
issue in the Trinko case. Long distance calls require local access origination and local access termination. These two services are under the control of a legal monopolist RBOC in the period 1981-1996. If an RBOC is allowed to provide long distance service as well, it can implement a vertical price squeeze against its pure long distance rivals, to be discussed in detail below. As a result of the vertical price squeeze, the profits of a pure long distance carrier can be diminished to the point that it is foreclosed from the market. In other words, in 1981 it was understood that allowing RBOCs in long distance would result in them leveraging their monopoly power from local markets into the long distance market and that would foreclose long distance competitors and diminish competition in long distance. ${ }^{12}$ To preserve and enhance competition in long distance,

${ }^{12}$ As the MFJ notes, in the presence of line of business restrictions there will be no incentive and ability for AT\&T (or the RBOCs) to engage in the anticompetitive conduct alleged.

... [T] he ability of AT\&T to engage in anticompetitive conduct stems largely from its control of the local Operating Companies. Absent such control, AT\&T will not have the ability to disadvantage competitors in the interexchange and equipment markets.

For example, with the divestiture of the Operating Companies AT\&T will not be able to discriminate against intercity competitors, either by subsidizing its own intercity services with revenues from the monopoly local exchange services, or by obstructing its competitors' access to the local exchange network. The local Operating Companies will not be providing interexchange services, and they will therefore have no incentive to discriminate. Moreover, AT\&T's competitors will be guaranteed access that is equal to that provided to AT\&T, and intercity carriers therefore will no longer be presented with the problems that confronted them in that area.

Id. at 165 . 
the MFJ imposed restrictions that prevented RBOCs from providing long distance service.

\section{A. Vertical Price Squeeze and Raising Rivals' Costs Leading to Foreclosure}

To understand the usefulness of business line restrictions in preventing anticompetitive behavior, consider a good that is comprised of two complementary parts $\mathrm{AB}$, and BC. Assume that both parts are necessary for the good to have value. Further assume that $\mathrm{AB}$ is monopolized while $\mathrm{BC}$ is competitive. The example to have in mind here for the $1981 \mathrm{AT} \& \mathrm{~T}$ breakup is AB being local originating access for a phone call and $\mathrm{BC}$ being long distance transmission. ${ }^{13}$ We are going to compare two industry structures. In the first industry structure with business restrictions, the monopolist of $\mathrm{AB}$ is not allowed to be in the $\mathrm{BC}$ market. In the second industry structure without business restrictions, the monopolist of $\mathrm{AB}$ is allowed in the $\mathrm{BC}$ market.

This was reaffirmed by the D.C. Circuit.

First. AT\&T will no longer have the opportunity to provide discriminatory interconnection to competitors. The Operating Companies will own the local exchange facilities. Since these companies will not be providing interexchange services, they will lack AT\&T's incentive to discriminate. Moreover, they will be required to provide all interexchange carriers with exchange access that is "equal in type, quality, and price to that provided to AT\&T and its affiliates." Proposed Decree, Section II. See Part VIII infra.

Id. at 171-72.

${ }^{13}$ A full analysis would require an additional service $C D$, also monopolized, which in the telecommunications context would be termination access. Because $\mathrm{AB}$ and $\mathrm{CD}$ play the same role, it is sufficient to analyze the model disregarding CD. 
When there are line of business restrictions, $\mathrm{AB}$ (originating access) is provided by the local monopolist, and $\mathrm{BC}$ (long distance transmission) by the competitive long distance sector. The price of the good $\mathrm{ABC}$ (the long distance call) is the sum of the price of originating access and long distance transmission

$$
\mathrm{P}_{\mathrm{ABC}}=\mathrm{P}_{\mathrm{O} . \mathrm{ACCESS}}+\mathrm{P}_{\mathrm{LD} . \text { TRANSMISSION }} .
$$

When there are no line of business restrictions on the local monopolist of $\mathrm{AB}$, it will also provide $\mathrm{BC}$ in competition with other long distance companies providing $\mathrm{BC}$. Now the local monopolist can control both the price of the composite good $\mathrm{ABC}, \mathrm{P}_{\mathrm{ABC}}$,

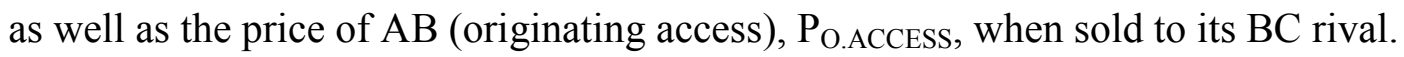
Thus, a pure long distance company that produces only $\mathrm{BC}$ would receive as revenue for its long distance transmission

$$
\mathrm{P}_{\mathrm{ABC}}-\mathrm{P}_{\mathrm{O} . \mathrm{ACCESS}} \text {. }
$$

Thus, the AB monopolist can "squeeze" the revenue of a pure long distance carrier to a very small amount. Setting any price $\mathrm{P}_{\mathrm{O} . \mathrm{ACCESS}}$ above its cost would disadvantage the long distance rival. ${ }^{14}$ Since the local monopolist charges itself its own cost for originating access, when the final products are homogeneous, even a small deviation of the price of originating access above its cost will result in foreclosure of an equally efficient long distance rival. This is called a vertical price squeeze. The wisdom of the line of business restrictions is that it avoids it.

\footnotetext{
${ }^{14}$ Access fees have been typically set at very high prices compared to cost with the regulatory objective of subsidizing basic service. See Nicholas Economides, Telecommunications Regulation: An Introduction, in The Limits And COMPleXity of ORganizations (Richard Nelson ed., Russell Sage Foundation Press 2004).
} 
The previous example depended on the assumption that the $\mathrm{AB}$ monopolist could set $\mathrm{P}_{\text {O.ACCESS }}$ above cost. Perfect regulation would set this price at cost. Even then, in the absence of line of business restrictions, the local monopolist can foreclose pure long distance rivals if it can implement raising rivals' costs strategies (such as delays and quality decreases) against them. To show that, suppose that the local monopolist can implement raising rivals' costs strategies that increase the effective cost of access to rivals to LOCAL.MONOPOLIST PRRC O.ACCESS $_{\text {above its costs for such services: }}{ }^{15}$

$$
\text { LOCAL.MONOPOLIST PRRC } \text { O.ACCESS }_{\text {LOCAL.MONOPOLIST }} \mathrm{C}_{\text {O.ACCESS }} \cdot
$$

Assuming that a long distance company, say AT\&T, has the same cost of long distance transmission as the local monopolist (the two are equally efficient),

$$
{ }_{\text {AT\&T }} P_{\text {LD.TRANSMISSION }}={ }_{\text {LOCAL.MONOPOLIST }} P_{\text {LD.TRANSMISSION }} \text {. }
$$

Then, faced with higher effective cost for access origination, equally efficient long distance rivals will have to charge a higher price ${ }_{A T \&}{ } P_{A B C}$ for the final service than the local monopolist's price LOCAL.MONOPOLIST $\mathrm{P}_{\mathrm{ABC}}$ and will therefore be foreclosed from the long distance market, as seen below.

$$
\begin{aligned}
& { }_{\text {AT\&T }} P_{\text {ABC }}={ }_{\text {LOCAL.MONOPOLIST }} P R R C_{\text {O.ACCESS }}+{ }_{\text {AT\&T }} P_{\text {LD.TRANSMISSION }}= \\
& \text { LOCAL.MONOPOLIST PRRC } \mathrm{O}_{\text {.ACCESS }}+{ }_{\text {LOCAL.MONOPOLIST }} \mathrm{P}_{\text {LD.TRANSMISSION }}> \\
& \text { LOCAL.MONOPOLIST } \mathrm{C}_{\text {O.ACCESS }}+{ }_{\text {LOCAL.MONOPOLIST }} \mathrm{P}_{\text {LD.TRANSMISSION }}={ }_{\text {LOCAL.MONOPOLIST }} \mathrm{P}_{\mathrm{ABC}}
\end{aligned}
$$

\footnotetext{
${ }^{15}$ Price when opponent Raises Rivals' Costs (PRRC) represents the effective price of the monopolized input to a downstream rival when the upstream monopolist uses a strategy that raises the costs of rivals or reduces their quality. LOCAL.MONOPOLIST $P R R C_{\text {O.ACCESS }}$ is the effective cost of access origination faced by long distance service rivals as a result of the local monopolist's raising rivals' costs actions.
} 
Therefore, when the local monopolist implements raising rivals' costs strategies, AT\&T is forced to sell its long distance service above the price at which the vertically integrated local monopolist sells it:

$$
\text { AT\& } \mathrm{P} \mathrm{P}_{\mathrm{ABC}}>\text { LOCAL.MONOPOLIST } \mathrm{P}_{\mathrm{ABC}} \text {. }
$$

Thus, in the absence of line of business restrictions, even under perfect price regulation, a local monopolist can implement raising rivals' costs strategies, disadvantage and even foreclose downstream rivals.

In summary, understanding that a vertical price squeeze and raising rivals' costs strategies can diminish competition in long distance, the government required in 1981 that RBOCs not be allowed to offer long distance service. In the abstract, in the absence of line of business restrictions a monopolist that sells an input required by his downstream competitors can diminish competition in a downstream market by using price discrimination and raising rivals' costs strategies. As we will see this applies directly to Verizon's the alleged behavior in Trinko.

\section{B. The Telecommunications Act of 1996 and its Implementation}

The 1996 Act was a brave attempt to introduce competition in all telecommunications markets. ${ }^{16}$ Congress understood that it was uneconomic for firms to

\footnotetext{
${ }^{16}$ See Nicholas Economides, Telecommunications Regulation: An Introduction, in THE LIMITS AND COMPLEXITY OF ORGaniZATIONS (Richard Nelson ed., Russell Sage Foundation Press 2004) discussing the 1996 Act; Nicholas Economides, U.S. Telecommunications Today, in IS MANAGEMENT HANDBOOK (Carol V. Brown \& Heikki Topi eds., Auerbach Publications 2003) available at http://www.stern.nyu.edu/networks/US2002.pdf .
} 
enter in local telecommunications by replicating the infrastructure of the incumbents. ${ }^{17}$ Thus, it set up two additional possibilities for entrants (besides entering with their own facilities): (i) to enter by leasing parts of the incumbents' local telecommunications network, known as unbundled network elements ("UNEs") ${ }^{18}$ and (ii) to enter by buying in wholesale the incumbents' services and reselling them. The most important avenue to entry was leasing all the UNEs (known as UNE-platform, or "UNE-P"), combining the UNE-P with the entrant's retail services (such as marketing and billing) and then selling

${ }^{17}$ As the Federal Communications Commission stated:

Because an incumbent LEC currently serves virtually all subscribers in its local serving area, an incumbent LEC has little economic incentive to assist new entrants in their efforts to secure a greater share of that market. An incumbent LEC also has the ability to act on its incentive to discourage entry and robust competition by not interconnecting its network with the new entrant's network or by insisting on supracompetitive prices or other unreasonable conditions for terminating calls from the entrant's customers to the incumbent LEC's subscribers.

Congress addressed these problems in the 1996 Act by mandating that the most significant economic impediments to efficient entry into the monopolized local market must be removed. The incumbent LECs have economies of density, connectivity, and scale; traditionally, these have been viewed as creating a natural monopoly. As we pointed out in our NPRM, the local competition provisions of the Act require that these economies be shared with entrants.

Federal Communications Commission, First Report and Order, FCC No. 96-325, at 1 10-11 (August 1, 1996).

${ }^{18} 47$ U.S.C. $\S \S 251(\mathrm{c})(3),(\mathrm{c})(6)$. The Federal Communications Commission defined the key UNEs as the "local loop," local switching, and local transport. See Federal Communications Commission, First Report and Order, FCC No. 96-325, at $§ 51.319$ (August 1, 1996). 
local service to final consumers. To facilitate entry, the 1996 Act set the price for UNEs at "cost plus a reasonable profit."." The 1996 Act additionally mandated that unbundled network elements be sold at "rates, terms, and conditions that are just, reasonable, and nondiscriminatory. ${ }^{20}$ To facilitate entry, the 1996 Act also imposed the requirement on an incumbent to allow for physical collocation of equipment at its premises, ${ }^{21}$ and on all companies the duty to provide number portability, so that consumers can keep their phone numbers if they change local service provider. ${ }^{22}$

The FCC adopted the long-run forward-looking economic cost as the measure of appropriate costs, or Total Element Long Run Incremental Costs (“TELRIC"). ${ }^{23}$ TELRIC is the sum of the costs for all economically efficient inputs required to supply

\footnotetext{
${ }^{19}$ The 1996 Act at 47 U.S.C. $§ 252$ (d)(1) orders that pricing of interconnection or unbundled network elements:
}

(A) shall be

(i) based on the cost (determined without reference to a rate-of-return or other rate-based proceeding) of providing the interconnection or network element (whichever is applicable), and

(ii) nondiscriminatory, and

(B) may include a reasonable profit.

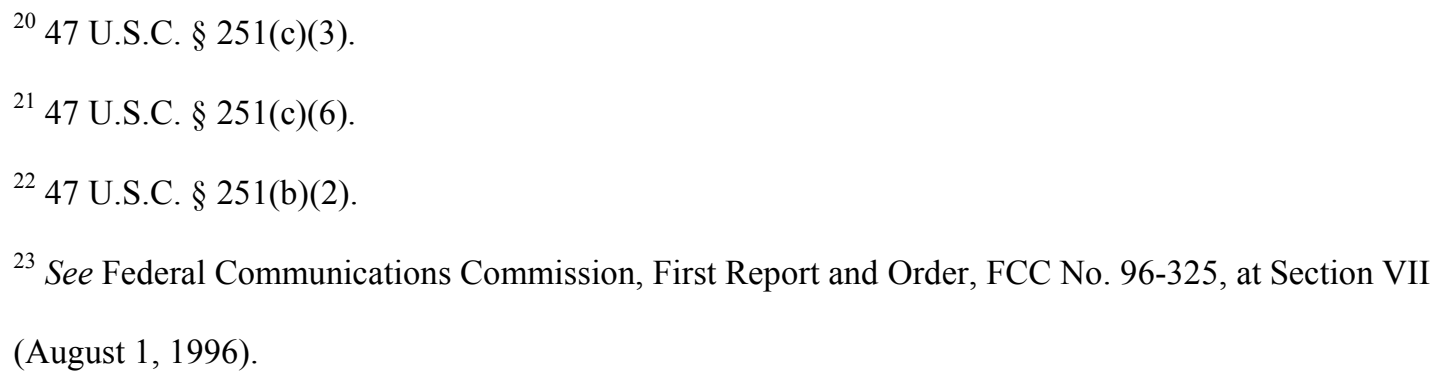


the UNE. ${ }^{24}$ TELRIC has the following features: (1) it is a forward-looking economic cost; (2) it is the least cost to provide the service; (3) it is a long run cost; (4) it is an incremental cost; (5) it includes a competitive return on capital; (6) it excludes monopoly rents; (7) it excludes cross subsidies of any kind; and (8) in general, it reflects cost differences among geographic regions. ${ }^{25}$

Prices based on TELRIC plus a reasonable profit, as mandated by the Act, for leasing of UNEs are clearly above the present cost of the local telecommunications network. $^{26}$ The present cost of the local telecommunications network reflects the cost of present-day resources that would be necessary to construct such a network. ${ }^{27}$ Thus, from an economic point of view it is the appropriate cost measure, and it was correctly adopted by the FCC. ${ }^{28}$ The incumbent local exchange carriers had argued that the appropriate cost measure would be the historic or "embedded" cost of the network, that is, the

\footnotetext{
${ }^{24}$ Federal Communications Commission, First Report and Order, FCC No. 96-325, at Section F 51.505 (August 1, 1996).

${ }^{25} I d$.

${ }^{26}$ See Federal Communications Commission, First Report and Order, FCC No. 96-325, at Section VII (August 1, 1996).

${ }^{27}$ See id., at $\S$ F 51.505 .

${ }^{28}$ Id. The FCC did not calculate the cost of the most efficient current network. Instead it allowed for the locations of switches and central offices of the incumbents to be fixed and calculated the cost of creating a present-day network given these locations. Since these locations could also be optimized in the most efficient network, the cost of the network as calculated by the FCC was in fact higher than that of the most efficient network. Because it kept the old locations of switches and central offices fixed, the network design approved by the FCC has been called a "scorched node" network design.
} 
historic cost of the network whenever it was constructed. ${ }^{29}$ However, the historic construction cost of the network does not generally correspond to the cost of present day resources to construct such a network. ${ }^{30}$ There could be many reasons for that, but I just highlight two that show how inappropriate it would be to use historic costs, especially in the case of local telecommunications.

First, technological change implies very significant cost reductions in the provision of telecommunications services. ${ }^{31}$ For example, a key function in telecommunications is switching and routing calls. Since the 1950 s, this is done by computers, where technological progress has been tremendous. To say that the appropriate cost today of a present day PC is billions of dollars because producing a computer with the corresponding computing power would cost that much in 1960 is totally absurd. The incumbents' proposal of using historic costs in the face of fast technological change is equally absurd.

Second, telecommunications companies were regulated for a significant period according to "rate of return regulation." Under such regulation, the company was guaranteed to recover its network infrastructure investments. The rate of return was set by the regulator and the company adjusted its capital base and prices so that its profits would not exceed the capital base times the rate of return. ${ }^{32}$ An expansion of the capital base by a dollar increased the allowed profits. Since this regulation guarantees recovery

\footnotetext{
${ }^{29}$ See id.

${ }^{30} I d$.

${ }^{31}$ See generally Economides, supra note 16.

${ }^{32}$ See Harvey Averch \& Leland L. Johnson, Behavior of the Firm Under Regulatory Constraint, 52 AM. ECON. REVIEW 1052, 1053-1069 (1962); Noll \& Owen, supra note 10.
} 
of investment and allows for expansion of profits when the capital base is increased, it is clear that regulated telecommunications companies had incentives to keep their capital base high. Thus, the incumbent local exchange carriers have historically kept their capital base high, and the key element of this capital base is the local network infrastructure. ${ }^{33}$ Therefore, even if historical costs were the appropriate measure of costs (which they are not) the historical costs of the incumbents would have to be significantly adjusted downward because of the distortions caused by the rate of return regulation. ${ }^{34}$

The 1996 Act also allowed entry of RBOCs in long distance, once they fulfilled various requirements related to opening their local markets to competition. ${ }^{35}$ From the point of view of an RBOC, long distance entry was supposed to be the reward for allowing competition in the local exchange and losing its local exchange monopoly. The 1996 Act was based on the assumption that the individual private incentives of the RBOCs would be sufficient to lead them to open local markets to competition. The 1996 Act did not impose penalties for delays in implementation or non-compliance. The lack of penalties has proved to be a very serious deficiency of the Telecommunications Act. ${ }^{36}$ Congress thought that the "carrot" of entry in long distance would be sufficient reward for RBOCs to open their local network. Recent history has shown that Congress erred in

\footnotetext{
${ }^{33}$ AT\&T long distance repeatedly adjusted its book value downward after competition developed in the long distance market to eliminate the distortion caused by the rate of return regulation to the book value it inherited. The RBOCs and GTE have not done so.

${ }^{34}$ Moreover, it is likely that incumbent local exchange carriers have already recovered the original cost of the vast majority of the physical plant that was in place by 1996.

${ }^{35} 47$ U.S.C. § 271 (1996).

${ }^{36}$ See generally Economides, supra note 16.
} 
this assumption. RBOCs' behavior showed that they preferred not to open their local network and pay the price of staying out of long distance for a while.

Implementation of the 1996 Act was very slow because of a variety of legal challenges and long delays in the creation of electronic and other systems that would allow large numbers of accounts to be moved across local telecommunications carriers in a way that is similar to the practice in long distance. There were significant allegations of various acts by incumbent monopolists to raise the costs of their rivals or lower their quality. ${ }_{-}{ }^{37}$ These acts included disconnection for a few days of customers that were switching telecommunications companies.

Besides litigation resulting from the implementation of the 1996 Act in nearly all the states, the FCC rules were challenged by the RBOCs and GTE. The Supreme Court invalidated the first set of FCC rules in AT\&T Corp. v. Iowa Utilities Board. ${ }^{38}$ The Court of Appeals for the D.C. Circuit invalidated much of the second set of FCC rules in United States Telecom Ass'n v. Federal Communications Commission. ${ }^{39}$ The FCC consolidated

\footnotetext{
${ }^{37}$ See, e.g., MCI Telecommunications Corp. v. Pacific Bell, Cal. P.U.C. Case No. 96-12-026, 1997 WL 781839 (Cal. P.U.C. 1997); Cal. P.U.C. Decision 01-05-087 (May 24, 2001); and Caltech International Telecom Corp. v. Pacific Bell, No. 97-2105 (N.D. Cal. 2000) (discussing California Public Utilities Commission investigation proceedings). The Trinko case itself was based on facts that emerged from an earlier New York Public Service Commission investigation of violations by NYNEX (Verizon's predecessor) of its interconnection agreement with a CLEC, AT\&T. NYNEX paid $\$ 10$ million to AT\&T and other competitors for losses arising from violations of its interconnection agreement. See Trinko, 540 U.S. at $402-405$.

${ }^{38} 525$ U.S. 366 (1999).

${ }^{39} 290$ F.3d 415 (D.C. Cir. 2002).
} 
the remand with its second triennial review of the rules implementing the Act. ${ }^{40}$ Subsequent litigation focused on the issue of "impairment," as described in section 251(d)(2)(B) of the Act. Section 251(d)(2) reads:

(2) In determining what network elements should be made available for purposes of subsection (c)(3), the Commission shall consider, at a minimum, whether--

(A) access to such network elements as are proprietary in nature is necessary; and

(B) the failure to provide access to such network elements would impair the ability of the telecommunications carrier seeking access to provide the services that it seeks to offer. $^{41}$

After losing its first appeal, the FCC defined impairment as follows: an entrant competitive local exchange carrier (CLEC) would "be impaired when lack of access to an incumbent [local exchange carrier] network element poses a barrier or barriers to entry, including operational and economic barriers, that are likely to make entry into a market uneconomic. $" 42$ In the appeal of the second triennial review of the FCC, referred to generally as the USTA II decision, the D.C. Circuit struck down the FCC's findings that

\footnotetext{
${ }^{40} \mathrm{See}$ Report and Order and Order on Remand and Further Notice of Proposed Rulemaking, Review of the Section 251 Unbundling Obligations of Incumbent Local Exchange Carriers, FCC No. 03-36 (Feb. 20, 2003) (“TRO”).

${ }^{41} 47$ U.S.C. § 251(d)(2) (1996).

${ }^{42}$ TRO, supra note 25 , at 984.
} 
entrants would be impaired nationwide with respect to mass market switching. ${ }^{43}$ As a result of this appeals decision and the FCC's subsequent order on remand, ${ }^{44}$ RBOCs do not have to set up new leases of the "local switching" UNE at prices that reflect cost plus a reasonable profit.

As an immediate consequence of USTA II, in the summer of 2004, AT\&T, the largest long distance carrier, stopped marketing both local and long distance service to residential customers. MCI acted similarly without a formal announcement. Since then SBC has acquired AT\&T and Verizon has acquired MCI. These mergers represent a significant reduction in the number and capabilities of independent long distance competitors, which may even result in price increases in long distance service.

On balance the 1996 Act failed in its main objectives. It failed to create competition in local telecommunications. It also failed to guard against RBOCs leveraging their monopoly power in the long distance market. As a result of the 1996 Act's lack of guard against RBOCs leveraging their monopoly power in the long distance market, the largest pure long distance companies were practically driven out of the residential long distance market followed by acquisitions of AT\&T and MCI by the upstream monopolists.

\footnotetext{
${ }^{43}$ See United States Telecom Ass'n v. Federal Communications Comm’n, 359 F.3d 554, 594-95 (D.C. Cir. 2004).

${ }^{44}$ Order on Remand, In the Matter of Unbundled Access to Network Elements, Review of the Section 251 Unbundling Obligations of Incumbent Local Exchange Carriers, FCC No. 04-290 (Dec. 15, 2004).
} 


\section{The Supreme Court Decision in Trinko}

The Supreme Court's Trinko decision had four parts. Part I described the complaint and procedural history of the case. ${ }^{45}$ Part II considered "what effect (if any) the 1996 Act has upon the application of traditional antitrust principles," that "the 1996 Act preserves claims that satisfy existing antitrust standards [but] does not create new claims that go beyond existing antitrust standards." ${ }^{, 47}$ Part III held that "Verizon's alleged insufficient assistance in the provision of service to rivals is not a recognized antitrust claim under [the Supreme] Court's existing refusal-to-deal precedents."48 Part IV considered whether to extend the Court's existing refusal-to-deal precedents to recognize a $\S 2$ claim for failure to comply with the requirements of the 1996 Act, and concluded that such an extension is unwarranted given the existing regulatory structure designed to enforce the requirements of the 1996 Act. $^{49}$

The Supreme Court majority held and reasoned as follows. First, that the 1996 Act did not create a different environment than the customary one in the application of antitrust law, despite the fact that the 1996 Act had an antitrust "savings clause.,"50 Second, the Court held that antitrust law only rarely requires cooperation of a monopolist

\footnotetext{
${ }^{45}$ Trinko, 540 U.S. at $402-405$.

${ }^{46} I d$. at 405 .

${ }^{47} I d$. at 407.

${ }^{48} I d$. at 410.

${ }^{49} I d$. at $411-416$.

${ }^{50} I d$. at $405-07$.
} 
with rivals because (i) it can lead to collusion, ${ }^{51}$ (ii) it may retard innovation, ${ }^{52}$ and (iii) it may reduce investment. ${ }^{53}$ Third, the Court noted a difference that it considered important in comparing Trinko with Aspen Skiing, ${ }^{54}$ an important earlier Supreme Court decision on refusal to deal. In contrast with Aspen Skiing, the monopolist in Trinko did not sell or lease the product at issue (parts of the local telecommunications network) and then stop selling it or begin discriminating against rivals. Instead, the market for leased parts of the local telecommunications network in Trinko was created by regulatory fiat. The Court noted that "Aspen Skiing is at or near the outer boundary of $\S 2$ liability." 55 Fourth, the Court declined to apply the "Essential Facilities" doctrine to the facts in Trinko remarking that there was "no need to either recognize [the essential facilities doctrine] or to repudiate it ...."56 Finally, the Court stated that it did not want to get involved in detailed regulatory matters. $^{57}$

${ }^{51} I d$. at 408, "Moreover, compelling negotiation between competitors may facilitate the supreme evil of antitrust: collusion."

${ }^{52} I d$. at 407 , implied by allowing monopoly power and monopoly prices to provide incentives to innovate: "[t]o safeguard the incentive to innovate, the possession of monopoly power will not be found unlawful unless it is accompanied by an element of anticompetitive conduct."

${ }^{53} I d$. at 414, "Judicial oversight under the Sherman Act would seem destined to distort investment and lead to a new layer of interminable litigation, atop the variety of litigation routes already available to and actively pursued by competitive LECs.”

${ }^{54} 472$ U.S. 585 (1985).

${ }^{55}$ Id. at 409.

${ }^{56} I d$. at 411.

${ }^{57} \mathrm{Id}$. at 411-15. 
There are a number of aspects of the Supreme Court's decision that are problematic from an economist's point of view. To start with, the Court is concerned that negotiations between the contracting parties (Verizon and AT\&T) would result in collusion. ${ }^{58}$ This should be a general concern but has no application in this case because here the contracting parties were in purely adversarial positions. Verizon was in possession of a local telecommunications network and AT\&T had no local network. This is the antithesis of the situation faced by sellers of substitutes where the possibility of collusion exists. Here the relationship was between a buyer and a seller. The FCC noted Congress recognized that, because of the incumbent LEC's incentives and superior bargaining power, its negotiations with new entrants over the terms of such agreements would be quite different from typical commercial negotiations. As distinct from bilateral commercial negotiation, the new entrant comes to the table with little or nothing the incumbent LEC needs or wants. ${ }^{59}$ Negotiations and contracts between parties in these circumstances do not typically raise antitrust concerns. Additionally, the parties had the obligation to negotiate imposed by the 1996 Act, so the Court's concern seems misguided. ${ }^{60}$

\footnotetext{
${ }^{58} I d$. at 408, ("Moreover, compelling negotiation between competitors may facilitate the supreme evil of antitrust: collusion.”).

${ }^{59}$ See Federal Communications Commission, First Report and Order, FCC No. 96-325, at 15 (August 1, 1996).

${ }^{60}$ Section 251(c) of the Telecommunications Act, 47 U.S.C. $§ 251(\mathrm{c})$ (1996) reads:
} 
The Trinko Court was also concerned that diminished investment in telecommunications infrastructure would result from the leasing requirement imposed by the 1996 Act. In principle, there should be no such concern from an antitrust point of view. Often, reduced investment results in higher welfare. Market processes typically help reduce redundant investment to the benefit of society. Moreover, the 1996 Act was written with a clear understanding that replication of the local telecommunications network was not only inefficient but prohibitively uneconomic. Thus, Congress created in the 1996 Act a regulatory framework that allowed entry and increased competition without necessarily any increase in investment in local telecommunications infrastructure. In imposing on incumbent local exchange carriers leasing at cost plus a reasonable profit, Congress decided against the replication of the local telecommunications network because it would have been inefficient. Thus, Congress explicitly chose regulatory rules that would tend to reduce investment in replicating the existing network infrastructure. ${ }^{61}$

(c) ADDITIONAL OBLIGATIONS OF INCUMBENT LOCAL EXCHANGE

CARRIERS- In addition to the duties contained in subsection (b), each incumbent local exchange carrier has the following duties:

(1) DUTY TO NEGOTIATE- The duty to negotiate in good faith in accordance with section 252 the particular terms and conditions of agreements to fulfill the duties described in paragraphs (1) through (5) of subsection (b) and this subsection. The requesting telecommunications carrier also has the duty to negotiate in good faith the terms and conditions of such agreements.

${ }^{61}$ Of course, the enhancement of competition in local telecommunications can lead to increased investment in infrastructure complementary to local telecommunications. 
The Supreme Court noted that the markets for leasing parts of the local telecommunications network were created by the 1996 Act and did not exist voluntarily earlier. The Court somehow believed that Verizon's refusal to deal and its related raising rivals' costs practices were somehow justified because infrastructure leasing prices were based on cost plus a reasonable profit: "Verizon's reluctance to interconnect at the costbased rate of compensation available under $\S 251(\mathrm{c})(3)$ tells us nothing about dreams of monopoly." ${ }^{\prime 2}$ But Verizon was a monopolist in the network infrastructure and in the network services markets. ${ }^{63}$ Reluctance to sell leases at above average cost prices is a clear indication that the monopolist in the networks infrastructure market is attempting through this action to prevent entry in the network services market which requires access to the networks infrastructure market.

The fact that Verizon was obligated to lease local telecommunications infrastructure at cost plus a reasonable profit and did not write such leases at any price earlier does not imply that Verizon's refusal to deal and raising rivals' costs strategies create antitrust liability. Markets are defined by demand for a service or a product. The fact that the market for leasing local telecommunications infrastructure did not exist before the 1996 Act is due to a number of reasons, and among them is the fact that competitors likely believed that they would not be profitable if they leased assets at the monopoly price. The fact that there was no demand at monopoly prices for such leases does not imply that there was no demand at any price. Clearly there was significant

\footnotetext{
${ }^{62}$ Trinko, 540 U.S. at 409.

${ }^{63}$ See Nicholas Economides, Katja Seim \& V. Brian Viard, Quantifying the Benefits of Entry into Local Phone Service at http://www.stern.nyu.edu/networks/Local_Telecommunications.pdf .
} 
demand at the "cost plus a reasonable profit" price, and most likely at prices above that. Thus, the possibility of a market existed before the 1996 Act. Should we deem that Verizon was justified not to sell or to raise rivals costs because it was denied the monopoly price? There is no viable economic argument that a refusal to deal at abovecost prices should not raise serious antitrust concerns. The Court should have ruled that Verizon's refusal to sell (or raising downstream rivals' costs resulting in lower sales) at prices above average cost was anti-competitive.

The Supreme Court compared Trinko with Aspen Skiing. The facts in Aspen Skiing were as follows: Aspen Skiing Co. controlled three out of four ski slopes in Aspen, Colorado with the fourth slope controlled by Aspen Highlands. Aspen Skiing and Aspen Highlands offered a joint ticket so that a buyer would be able to ski on all four slopes with revenue shared according to use. Aspen Skiing discontinued the joint ticket in 1978-79 and refused to sell its tickets to Aspen Highlands even at full retail price, to prevent Aspen Highlands from bundling them with its own tickets and recreating the joint ticket that had formerly been available. The Supreme Court ruled that Aspen Skiing's refusal to deal was anti-competitive. ${ }^{64}$

${ }^{64}$ Aspen Skiing, 472 U.S. at 593-608. The Court noted:

$[\mathrm{t}]$ he refusal to accept the Adventure Pack coupons in exchange for daily tickets was apparently motivated entirely by a decision to avoid providing any benefit to Highlands even though accepting the coupons would have entailed no cost to [Aspen Skiing Co.] itself, would have provided it with immediate benefits, and would have satisfied its potential customers. Thus the evidence supports an inference that [Aspen Skiing Co.] was not motivated by efficiency concerns and that it was willing 
The Trinko Court stated: “Aspen Skiing is at or near the outer boundary of $\S 2$ liability." 65 Taking that as given, one would expect Trinko to fall within the outer boundary set by Aspen Skiing. Because Verizon's price was set by regulation at cost plus a reasonable profit, it is reasonable to infer that Verizon's price to cost margin was lower than in the duopoly of Aspen Skiing. Thus, all else being equal, one would expect Verizon more likely to refuse to sell than Aspen Skiing Co. From the point of view of the firm committing the anti-competitive act, the incentive seems stronger for Verizon than for Aspen Skiing. Therefore, if the Supreme Court deems the refusal to deal by a duopolist in Aspen anti-competitive, it should find the refusal to deal by the monopolist in Trinko even more so.

Being forced by regulation to sell below the monopoly price, and unable to discriminate in price by regulatory restraints, the monopolist in Trinko has an incentive to raise the costs of its rivals. If regulation were not present, price discrimination and monopoly pricing would have likely made raising rivals' costs strategies sub-optimal form the monopolist's point of view and they would not have been used. In the regulatory environment of the 1996 Act, raising rivals' costs is a natural response of a monopolist to the restraints of regulation. ${ }^{66}$ Raising rivals' costs strategies reduce

\footnotetext{
to sacrifice short-run benefits and consumer goodwill in exchange for a perceived long-run impact on its smaller rival.

${ }^{65}$ Trinko, 540 U.S. at 409.

${ }^{66}$ See Nicholas Economides, The Incentive for Non-Price Discrimination by an Input Monopolist, 16 INT'L JOURNAL INDUS. ORG. 271 (1998).
} 
competition and social welfare associated from the existence of a free market. ${ }^{67}$ In applying an Aspen Skiing standard, the Court erred in not considering the significant difference in incentives of the potentially liable party between the unregulated environment in Aspen Skiing and the regulated environment of Trinko.

The Court stated that it did not want to get involved in regulatory matters, and that is understandable. However, since the Court had already accepted that the savings clause of the 1996 Act allowed for antitrust to be applied in parallel with sectoral regulation, nothing would prevent the Court from declaring, for example, that Verizon's degradation of service to AT\&T was anti-competitive, accepting the antitrust implications, and avoid getting the courts involved in regulatory issues. There is a long tradition of courts enforcement of the antitrust laws in telecommunications (as in United States v. $A T \& T^{68}$ ), despite the fact that the sector has been regulated since the 1930s.

The Court missed the vertical leveraging issue in Trinko which I discuss below. The discussion is an application of the vertical price squeeze and raising rivals' costs actions of a vertically integrated monopolist that were addressed earlier in the context of competition in long distance and the need for line of business restrictions. The same abstract framework applies. The only differences are the relevant markets and the names of the players.

\footnotetext{
${ }^{67}$ See generally Steven C. Salop \& David T. Scheffman, Raising Rivals' Cost, 73 AM. ECON. REVIEW 267 (1983), and Thomas G. Krattenmaker \& Steven C. Salop, Anticompetitive Exclusion: Raising Rivals' Costs to Achieve Power Over Price, 96 YALE L.J. 209 (1986).

${ }^{68}$ See Modification of Final Judgment or MFJ, formally United States v. American Tel. and Tel. Co., 552 F. Supp. 131 (D.C. Cir. 1982).
} 
Verizon provides two local telecommunications services: (i) network infrastructure services (NET services), which it provided to itself and to competitors in local telecommunications; and (ii) retail services. End-users consume a composite service comprised of NET services and retail services. Competitors to Verizon in retail local telecommunications buy only NET services adding their own retailing services for sale to end users.

When the 1996 Act was initially implemented, Verizon had a monopoly in both NET services and retail services. The conduct of Verizon in Trinko can be seen as the result of Verizon leveraging its monopoly in NET services to preserve its monopoly in retail services. This was recognized by the Second Circuit, which noted that Trinko "may have a monopoly leveraging claim" based on the fact that "the defendant '(1) possessed monopoly power in one market; (2) used that power to gain a competitive advantage ... in another distinct market; and (3) caused injury by such anticompetitive conduct." ${ }^{\prime 69}$ In contrast, the Supreme Court dismissed the vertical issue using a fallacious circular argument in footnote four of its decision, stating, "In any event, leveraging presupposes anticompetitive conduct, which in this case could only be the refusal-to-deal claim we have rejected. ${ }^{, 70}$ Here the key anti-competitive conduct was the leveraging from NET services to retailing services, as I explain below, and the Court missed that.

Using the earlier terminology, AB (NET services) is the monopolized good, and BC (retailing services) is the downstream good where there is competition after the 1996 Act. Only good ABC (local telecommunications services) is demanded by final

\footnotetext{
${ }^{69}$ Trinko, 305 F.3d at 108.

${ }^{70}$ Trinko, 540 U.S. at 415 n. 4.
} 
consumers. All firms in retailing services, including Verizon, require to use NET services to produce local telecommunications services. Profit maximization at the corporate level at Verizon implies that NET services is sold within the company at cost, VERIZON $C_{\text {NET. }}$. Thus, Verizon's price for local telecommunications to end users is

$$
{ }_{\text {Verizon }} P_{\text {LOCAL }}={ }_{\text {verizon }} C_{\text {Net }}+{ }_{\text {verizon }} P_{\text {Retailing }} .
$$

When Verizon sells NET services (leases its network), to rivals in the retailing services market at an above-cost price, i.e.,

$$
\text { VERIZON } \mathrm{P}_{\text {NET }}>\text { VERIZON } \mathrm{C}_{\mathrm{NET}} \text {, }
$$

then an equally efficient competitor in retailing, say AT\&T, would be forced out of business since it would have to charge a higher price that Verizon to final customers for local telecommunications service. To see this, assume that AT\&T and Verizon are equally efficient in providing retailing services, i.e.,

$$
{ }_{\text {at\&T }} P_{\text {Retailing }}={ }_{\text {Verizon }} P_{\text {Retailing. }}
$$

Then the price that AT\&T charges for local telecommunications services will be higher than Verizon's:

$$
\begin{aligned}
& { }_{\text {AT\&T }} \mathrm{P}_{\text {LOCAL }}={ }_{\text {VERIZON }} \mathrm{P}_{\text {NET }}+{ }_{\text {AT\&T }} \mathrm{P}_{\text {RETAILING }}= \\
& \text { Verizon }_{\text {NeT }}+{ }_{\text {Verizon }} P_{\text {RETAILING }}> \\
& \text { verizon } \mathrm{C}_{\mathrm{NeT}}+{ }_{\text {verizon }} \mathrm{P}_{\text {Retailing }}={ }_{\text {verizon }} \mathrm{P}_{\text {LOCAL }} .
\end{aligned}
$$

Therefore, if AT\&T leases UNEs (buys NET services) from Verizon above cost, AT\&T is forced to sell local telecommunications services above the price at which Verizon sells them:

$$
\text { AT\& } \mathrm{P}_{\text {LOCAL }}>\text { VERIZON } \mathrm{P}_{\text {LOCAL }} .
$$


In this way, AT\&T or any other rival in local telecommunications which has to lease UNEs from Verizon can be foreclosed provided that Verizon can price UNEs above cost.

Alternatively, now assume that Verizon is forced by regulators to lease UNEs (sell NET services) at cost. Verizon can use raising rivals' costs strategies towards its competitors in retailing services, such as delays and quality decreases, so that it increases the effective cost of NET services to them to the level ${ }_{\text {VERIZON }} \mathrm{PRRC}_{\mathrm{NET}},{ }^{71}$ which is above its cost for such services:

$$
\text { VERIZONPRRC } C_{\text {NET }}>\text { VERIZON } C_{\text {NET }} \text {. }
$$

Then, using the same argument as in the AT\&T 1981 divestiture, faced with higher effective costs for NET services, equally efficient retailing competitors will have to charge a higher price than Verizon's VERIZON $\mathrm{P}_{\text {LOCAL }}$ and will therefore be foreclosed from retailing services. That is, a rival that is equally efficient with Verizon in retailing,

$$
{ }_{\text {AT\& }} \mathrm{P}_{\text {Retailing }}={ }_{\text {verizon }} P_{\text {Retailing, }},
$$

will be forced to sell local telecommunications services at a higher price that Verizon:

$$
\begin{aligned}
& { }_{\text {AT\&T }} P_{\text {LOCAL }}={ }_{\text {VERIZON }} P_{R R C} C_{\text {NET }}+{ }_{\text {AT\&T }} P_{\text {RETAILING }}= \\
& \text { vERIZON }_{\text {PRRC }} \text { NET }+{ }_{\text {veRIZON }} P_{\text {RETAILING }}> \\
& { }_{\text {verizon }} \mathrm{C}_{\text {Net }}+{ }_{\text {verizon }} P_{\text {Retailing }}={ }_{\text {verizon }} P_{\text {Local }}
\end{aligned}
$$

It follows that, when Verizon implements raising rivals costs strategies, AT\&T is forced to sell local telecommunications services to final consumers above the price at which Verizon sells them:

$$
\text { AT\& } \mathrm{P}_{\text {LOCAL }}>\text { VERIZON } \mathrm{P}_{\text {LOCAL }}
$$

\footnotetext{
${ }^{71}$ VERIZON PRRC $_{\text {NET }}$ is the effective cost of NET services faced by Verizon local service rivals as a result of Verizon's raising rivals' costs actions.
} 
In summary, Verizon can use raising rivals' costs strategies to leverage its monopoly in NET services so that it forecloses its competitors in local telecommunications services. Moreover, Verizon has an incentive to do so, since this strategy allows it to maintain its profitable monopoly in local telecommunications services. Also note that the raising rivals' costs strategy can be used in addition to an increase in the price of NET services and that these two strategies are not in conflict with each other from Verizon's point of view.

\section{The Profit Sacrifice Principle and Its Application in Trinko}

The Supreme Court did not state a rule under which specific conduct will be found to be "willful monopolization." In its brief in Trinko, the government proposed such a standard based on the "sacrifice principle." $" 72$ I define the sacrifice principle as follows: a defendant is liable of anticompetitive behavior if its conduct "involves a sacrifice of short-term profits or goodwill that makes sense only insofar as it helps the defendant maintain or obtain monopoly power." ${ }^{, 73}$ This definition only partially

\footnotetext{
${ }^{72}$ Brief of Amici Curiae United States and the Federal Trade Commission in support of Trinko, 540 U.S. 398 (2004) (No. 02-682) at 16.

${ }^{73}$ As the Government's brief notes, the sacrifice principle has been used in various versions in Aspen Skiing, 472 U.S. at 608, 610-611 (conduct that "sacrifice[s] short-run benefits," such as immediate income and consumer goodwill, undertaken because it "reduc[es] competition over the long run"); General Indus. Corp. v. Hartz Mountain Corp., 810 F.2d 795, 803 (8th Cir. 1987) (conduct anticompetitive if "its 'anticipated benefits were dependent upon its tendency to discipline or eliminate competition and thereby enhance the firm's long term ability to reap the benefits of monopoly power."'); Stearns Airport Equip. Co. v. FMC Corp., 170 F.3d 518, 523-524 n.3 (5th Cir. 1999) (conduct exclusionary if it harms the monopolist but is justified because it causes rivals more harm); Advanced Health-Care Servs. v. Radford Cmty. Hosp.,
} 
coincides with the definition of the same principle in the Government's brief in Trinko. Specifically, the Government's brief allows all behavior that does not involve sacrifice of short term profits to be characterized as not "exclusionary" and not "predatory.",74 I disagree. Conduct can be exclusionary even without a sacrifice of short term profits. But when such a sacrifice is observed, it shows directly that this conduct being anticompetitive.

I am not endorsing the sacrifice principle as a single criterion to be used in ascertaining anti-competitive behavior since there can be cases where there is no shortterm profits sacrifice but conduct does not make sense except to attain or retain monopoly power. However, it is clear that if an action involves a sacrifice of short term profits that cannot be justified except to the extent that it helps a company to create, protect or enhance monopoly power, there is little doubt that such an action is anti-competitive. ${ }^{75}$

910 F.2d 139, 148 (4th Cir. 1990) ("making a short term sacrifice" that "harm[s] consumers and competition" to further "exclusive, anti-competitive objectives"). Id.

74 "Conduct is not exclusionary or predatory unless it would make no economic sense for the defendant but for its tendency to eliminate or lessen competition." Brief of Amici Curiae United States and the Federal Trade Commission at 15, Verizon Communications Inc. v. Law Offices of Curtis V. Trinko, 540 U.S. 398 (2004) (No. 02-682).

${ }^{75}$ It should also be noted that changes in total welfare or total surplus realized from a market (the sum of profits of all firms in the market plus consumers' surplus, where consumers' surplus represents the difference between the total willingness to pay for a certain number of units by consumers and the amount they actually pay) do not generally coincide with changes of profits of a dominant firm. Thus, a change in profits by one firm, even a monopolist, does not, in general, correspond to a corresponding equal change in welfare, or even a change in welfare in the same direction as the profit change. 
The vertical leveraging in Trinko passes the "sacrifice test." The behavior of Verizon to raise the costs of rivals in local telecommunications services entailed a sacrifice of profits from potential leasing of UNEs. This sacrifice would not have occurred if Verizon were not trying to protect its monopoly in the retail market for local telecommunications services. Thus, in applying the sacrifice principle, Verizon's actions are found to be anti-competitive.

If Verizon did not have a retailing division, it would have no incentive to foreclose or disadvantage independent retailing firms. Instead, if its strategy were not to preserve its monopoly position in retailing, Verizon would have had every incentive to sell its NET services to all at prices above cost, as mandated by the 1996 Act. Since Verizon sells its NET services to its retailing division at cost while any NET services price sold to third parties includes a reasonable profit (according to the 1996 Act's rules), raising rivals' costs actions that disadvantage third party retailing service firms and result in smaller sales of NET services to these firms clearly imposes a sacrifice of profits for Verizon. Therefore, the "sacrifice" principle can be applied in the Trinko case in the same way that the Supreme Court articulated it in Aspen Skiing to conclude that Verizon's raising rivals costs actions result in a short term sacrifice of profits and therefore would not have been taken except to preserve its monopoly.

\section{Conclusion}

The Supreme Court's economic reasoning in the Trinko decision has a number of defects from an economist's point of view. The decision is likely to enhance and preserve the monopoly of Verizon and the other RBOCs who remain near-monopolists in 
local telecommunications markets. The Supreme Court missed the leveraging of monopoly power from the network infrastructure market to the retail telecommunications market that Verizon engaged in to foreclose competition in the retail telecommunications market. Additionally, the Supreme Court used the fact that the leasing market for parts of the telecommunications network did not exist before being mandated by the 1996 Act to find that Verizon did not have antitrust liability. This is problematic since technological change can create new markets where none existed before, and the earlier non-existence of markets should not be used as an escape from antitrust law.

The Supreme Court decided Trinko in the context of Aspen Skiing where regulation was absent. However, the use of non-price strategies to raise rivals' costs is particularly important in Trinko because of the price regulation imposed by the 1996 Act. Even in the context of Aspen Skiing, the Court erred in not allowing the logic of Aspen Skiing to be applied to Trinko. The Court had applied the sacrifice principle in Aspen Skiing, showing that Aspen Skiing's actions had sacrificed short term profits. Here the Court failed to apply the same principle, because it is clear that Verizon's actions caused it to lease less infrastructure at above-cost prices and therefore to incur a profits sacrifice. 